\title{
Optimal fiscal management of commodity price shocks
}

DOI:

10.1016/j.jdeveco.2016.05.005

\section{Document Version}

Accepted author manuscript

Link to publication record in Manchester Research Explorer

\section{Citation for published version (APA):}

Agenor, P-R. (2016). Optimal fiscal management of commodity price shocks. Journal of Development Economics, 122, 183-196. https://doi.org/10.1016/j.jdeveco.2016.05.005

\section{Published in:}

Journal of Development Economics

\section{Citing this paper}

Please note that where the full-text provided on Manchester Research Explorer is the Author Accepted Manuscript or Proof version this may differ from the final Published version. If citing, it is advised that you check and use the publisher's definitive version.

\section{General rights}

Copyright and moral rights for the publications made accessible in the Research Explorer are retained by the authors and/or other copyright owners and it is a condition of accessing publications that users recognise and abide by the legal requirements associated with these rights.

\section{Takedown policy}

If you believe that this document breaches copyright please refer to the University of Manchester's Takedown Procedures [http://man.ac.uk/04Y6Bo] or contact uml.scholarlycommunications@manchester.ac.uk providing relevant details, so we can investigate your claim.

\section{OPEN ACCESS}




\title{
Optimal Fiscal Management of Commodity Price Shocks
}

\author{
Pierre-Richard Agénor* \\ Final version: June 15, 2016. Published in \\ Journal of Development Economics, 122 (September 2016), 183-96
}

\begin{abstract}
This paper analyzes how low-income countries should optimally respond, through fiscal policy, to commodity price shocks. The model accounts for imperfect access to world capital markets and a variety of externalities associated with public infrastructure, including utility benefits, a direct complementarity effect with private investment, and reduced distribution costs. However, public capital is also subject to congestion and absorption constraints, with the latter affecting the efficiency of infrastructure investment. The optimal windfall allocation rule between spending today and asset accumulation is determined so as to minimize a social loss function defined in terms of the volatility of private consumption and either the nonresource primary fiscal balance or a more general index of macroeconomic stability, which accounts for the volatility of the real exchange rate.
\end{abstract}

JEL Classification Numbers: F41, H41, H54

\footnotetext{
*University of Manchester, United Kingdom, and Centre for Growth and Business Cycle Research. I am grateful to Alessandro Flamini for useful discussions, the Editor and two anonymous referees for many helpful comments, and to Keyra Primus for research assistance. A more detailed version of the paper, containing technical Appendices A, B and C, is available upon request.
} 


\section{Introduction}

The design of fiscal policy in developing countries with large endowments of non-renewable natural resources continues to generate much debate among economists and policymakers. While the economic rents created by high commodity prices, or the discovery of new reserves, provide an opportunity to promote economic growth and human development in these countries, managing those resources effectively has proven to be a daunting challenge. Time and again the abundance of natural resources has led to a so-called natural resource curse (van der Ploeg (2011)). Global commodity price volatility has often translated into domestic macroeconomic instability, especially in resource-rich developing countries where exports and government revenues are highly concentrated. At the same time, large and sustained inflows of foreign exchange associated with resource windfalls have led to Dutch disease effects, that is, a contraction of domestic production of nonresource traded goods resulting from increased demand for nontraded goods and a real exchange rate appreciation.

Much of the debate on natural resource management has been dominated by the permanent income hypothesis (PIH) approach. The standard PIH approach implies that, for a country where the only source of government revenues is resource income, the intertemporal budget constraint is satisfied when the nonresource primary deficit is limited to the perpetuity value of resource wealth, that is, the present value of all future resource revenue. From that perspective, the PIH provides a benchmark for the nonresource primary fiscal balance that can be financed indefinitely. ${ }^{1}$

However, some recent research has questioned the relevance of the PIH for resource-rich low-income countries. In particular, it has been argued that the PIH is not appropriate for these countries, because it ignores the fact that they suffer from significant weaknesses in terms of access to core physical infrastructure. ${ }^{2}$ Indeed, the narrow interpretation of the PIH - that resource windfalls should be saved in their entirety in the form of financial assets held abroad - ignores the fact that lack of access to infrastructure imposes severe

\footnotetext{
${ }^{1}$ With projections for nonresource revenue, the nonresource primary balance benchmark also provides an estimate of the "sustainable" level of expenditure (Baunsgaard et al. (2012), Lundgren et al. (2013)).

${ }^{2}$ The (in)appropriateness of the conventional PIH prescription has been discussed by Collier et al. (2010), Gelb (2011), van der Ploeg (2011), Baunsgaard et al. (2012), and Lundgren et al. (2013), considering the large development needs of low-income developing countries.
} 
constraints on economic activity in poor countries, and that investments in infrastructure, given their lumpy nature, may need to be raised significantly over the short to medium run to create a Big Push (see Agénor (2010; 2012, Chapter 6)). As documented by Geiregat and Yang (2013), infrastructure indicators in resource-rich developing countries continue to be either worse (paved roads, for instance) or no better (access to improved water, for instance), than in nonresource-rich developing countries, regardless of their income per capita status. ${ }^{3}$ The key issue therefore has been to devise more flexible fiscal management rules that allow governments, in response to resources windfalls, to allocate sufficient resources to meet short-term needs in infrastructure investment and possibly other components of productive spending, while at the same time maintaining fiscal and macroeconomic stability, achieving long-term fiscal sustainability, and ensuring adequate savings for future generations.

A number of analytical contributions have attempted to address these issues. Several of them bring together elements of the literature on the optimal management of resource windfalls and the literature on the Dutch disease. In an important contribution, van der Ploeg and Venables (2013) found that, compared to the PIH prescription it may be optimal to place less of a revenue windfall in offshore funds in the long run, because of the need to finance higher public investment, but more in the short run, because of absorption constraints. Berg et al. (2013) developed a three-sector dynamic stochastic general equilibrium (DSGE) model with a financial side to discuss both fiscal and monetary policy responses to natural resource price shocks. To capture absorptive capacity constraints, the efficiency of public investment is assumed to be negatively related to the level of investment itself. In the same vein, Araujo et al. (2016) developed a two-sector model with private and public investment, as well as several frictions, including absorptive capacity constraints, inefficiencies in investment, and borrowing constraints. The model is used to study how these frictions, and the behavior of investment, affect current account dynamics associated with commodity price shocks. However, none of these contributions addresses directly the issue of the optimal allocation of resource windfalls in a stochastic environment.

\footnotetext{
${ }^{3}$ See Foster and Briceño-Garmendia (2010) for the role of transport costs - the highest of any regionin Sub-Saharan Africa.
} 
This paper contributes to the ongoing debate by developing a DSGE model to study the optimal fiscal response to resource price shocks in a low-income country where access to infrastructure is limited. Specifically, the model is used to compare macroeconomic outcomes under alternative fiscal approaches to investing resource revenue, and to determine the optimal allocation between saving and investment. It explicitly accounts for imperfect access to world capital markets, government spending on infrastructure, the inefficiency of such spending, and absorptive capacity constraints.

In modeling the externalities associated with public capital, the model accounts not for only for standard productivity effects but also for direct utility benefits, a direct complementarity effect with private investment, and reduced distribution costs. At the same time, public capital is subject to congestion and absorption constraints, which adversely affect the efficiency of infrastructure spending. Importantly as well, the paper argues that the optimal allocation of resources must be determined on the basis of a social loss function that combines not only a measure of household welfare (namely, consumption volatility) but also an indicator of fiscal or macroeconomic volatility. This matters because in practice policymakers in poor countries have shown time and again explicit concern with the instability that commodity price shocks (as noted earlier) often impart to their economies. In such conditions, an optimal rule based solely on maximizing household welfare may not provide an adequate foundation for policy advice. Put differently, the analysis takes into account the revealed preferences of policymakers, rather than considering only a benevolent agent that maximizes the utility of the representative household.

The model is parameterized and used first to examine the transmission process of a temporary resource price shock under cash transfers (that is, the windfall is transferred entirely to citizens), full spending, and full saving in a sovereign fund. Under the first two rules, the model is able to account for the key stylized facts associated with a resource windfall, namely, the Dutch disease effects alluded to earlier. The optimal allocation rule between spending today and asset accumulation is then determined so as to minimize a social loss function defined in terms of the volatility, relative to the benchmark case, of private consumption and either the nonresource primary balance or a more general index of macroeconomic stability, which accounts for the volatility of the real exchange rate. In either case, the key result is that the choice between spending now and spending later 
involves a dynamic volatility trade-off. Initially, full spending creates a lot of volatility; increasing the share of a resource windfall that is saved (or equivalently, reducing the share spent today) tends at first to reduce that volatility. However, as the proportion of resource revenues that is saved continues to rise, the interest income from the assets held in the sovereign fund become larger, and this tends to raise spending over time, which tends to increase volatility once again. In general, neither full spending, nor full saving, represents an optimal fiscal response to resource windfalls. In addition, the optimal policy is always better, in terms of its impact on macroeconomic volatility, than an unconditional cash transfer policy.

The remainder of the paper is organized as follows. Section 2 describes the model, whereas section 3 discusses the steady-state solution and log-linearization. Section 4 presents a parameterization for a "typical" low-income country. As a preliminary step, and to establish the model as an adequate benchmark for further analysis, section 5 defines three alternative fiscal rules (cash transfers, and full allocation of resource windfalls to either public spending or accumulation in a sovereign fund) and examines the dynamics of a temporary resource price increase. In Section 6 the optimal allocation rule between spending today and asset accumulation is determined. Section 7 discusses some sensitivity analysis. The final section offers some concluding remarks.

\section{The Model}

Consider an open economy with three sectors producing a non-renewable resource (oil from now on, and identified with superscript $O$ ), a nonoil tradable good (superscript $T$ ), and a nontradable good (superscript $N$ ). Oil output, $Y_{t}^{O}$, is a flow endowment owned by the government; its extraction requires no use of factor resources. It is not consumed domestically and only provides an additional source of tax revenue from exportables. Tradable output, $Y_{t}^{T}$, and nontradable output, $Y_{t}^{N}$, are produced competitively. The nontradable good is a perishable, pure consumption good, whereas the nonoil tradable good is a mixed good, which can be either consumed or invested. Private investment (equipment) consists of tradables only, whereas public investment consists of both tradables and nontradables. ${ }^{4}$

\footnotetext{
${ }^{4}$ Private investment is viewed here as consisting of imported equipment, whereas public consumption, defined later, is viewed as consisting to a large extent of wages and salaries. These assumptions are fairly
} 
Capital and labor are both perfect mobile between the tradable and nontradable sectors.

Both households and the government spend on tradables and nontradables and can borrow on world capital markets. ${ }^{5}$ However, the cost of borrowing incorporates a risk premium, which depends on the country's external debt (scaled by tradable output) and the composition of output, which measures the capacity to repay.

\subsection{Oil Production and Prices}

Oil production follows an exogenous deterministic process, such that

$$
\frac{Y_{t}^{O}}{\tilde{Y}^{O}}=\left(\frac{Y_{t-1}^{O}}{\tilde{Y}^{O}}\right)^{\rho_{Y} O}
$$

where $\tilde{Y}^{O}$ is the steady-state value of $Y_{t}^{O}$ and $\rho_{Y^{O}} \in(0,1)$ is an autoregressive coefficient, which (as discussed later) is related to the rate of depletion of oil resources.

The country's oil production is assumed to be small relative to world supply. The price of oil on world markets (relative to the foreign-currency price of nonoil tradables), $P_{t}^{O}$, follows therefore an exogenous process, which is assumed to be stochastic:

$$
\frac{P_{t}^{O}}{\tilde{P}^{O}}=\left(\frac{P_{t-1}^{O}}{\tilde{P}^{O}}\right)^{\rho_{P} O} \exp \left(\epsilon_{t}^{P^{O}}\right)
$$

where $\tilde{P}^{O}$ is the steady-state value of $P_{t}^{O}, \rho_{P} \in(0,1)$ is an autoregressive coefficient, and $\epsilon_{t}^{P^{O}}$ a normally distributed random shock with zero mean and a constant variance.

\subsection{Nonoil Tradable Production}

Nonoil tradable goods are produced competitively using labor, in quantity $L_{t}^{T}$, private capital, $K_{t}^{T}$, and public capital, $K_{t}^{I}$. The production function of these goods is given by

$$
Y_{t}^{T}=Q_{t-1}^{T}\left(L_{t}^{T}\right)^{\beta}\left(K_{t}^{T}\right)^{1-\beta}\left(\frac{K_{t}^{I}}{K_{t}^{P}}\right)^{\omega_{T}},
$$

where $\beta \in(0,1), \omega_{T}>0, K_{t}^{P}$ is the aggregate private capital stock, and $Q_{t}^{T}$ a productivity factor, which operates with a lag to capture gradual diffusion effects. Although public reasonable for a low-income country. Changing them-by assuming that private investment also involves some spending on nontradables as well, or that government spending consists also in part of tradableswould affect the magnitude of the response of the real exchange rate, rather than its direction.

${ }^{5}$ Many low-income countries in Sub-Saharan Africa are now able to borrow on international financial markets; see Sy (2013) for a discussion. 
capital is nonexcludable, it is partially rival and subject to congestion. For simplicity, congestion is measured in terms of the aggregate stock of private capital.

Given equation (3), firms maximize profits, defined as $\Pi_{t}^{T}=Y_{t}^{T}-w_{t} L_{t}^{T}-r_{t}^{K} K_{t}^{T}$, where $w_{t}$ is the economy-wide wage rate (measured in terms of foreign currency) and $r_{t}^{K}$ the economy-wide rental rate of capital. Factor prices and the aggregate private capital stock are taken as given in solving this optimization problem. First-order conditions take the standard form

$$
\begin{gathered}
w_{t}=\beta\left(\frac{Y_{t}^{T}}{L_{t}^{T}}\right), \\
r_{t}^{K}=(1-\beta)\left(\frac{Y_{t}^{T}}{K_{t}^{T}}\right) .
\end{gathered}
$$

Productivity in the tradable sector is endogenous and evolves according to a learningby-doing mechanism, along the lines discussed by Torvik (2001). Specifically, productivity increases with the share of the population employed in the tradable sector:

$$
Q_{t}^{T}=Q^{T, 0}\left(\frac{L_{t}^{T}}{L_{t}}\right)^{\nu_{T}}
$$

where $Q^{T, 0}>0$ and $\nu_{T} \in(0,1)$.

\subsection{Nontradable Production}

Nontradable goods are produced competitively using also labor, $L_{t}^{N}$, private capital, $K_{t}^{N}$, and public capital. The production function is given by

$$
Y_{t}^{N}=Q^{N}\left(L_{t}^{N}\right)^{\eta}\left(K_{t}^{N}\right)^{1-\eta}\left(\frac{K_{t}^{I}}{K_{t}^{P}}\right)^{\omega_{N}},
$$

where $\eta \in(0,1), \omega_{N}>0$, and $Q^{N}$ is a time-invariant productivity parameter.

Given (7), firms maximize profits, defined as $\Pi_{t}^{N}=P_{t}^{N} Y_{t}^{N}-w_{t} L_{t}^{N}-r_{t}^{K} K_{t}^{N}$, where $P_{t}^{N}$ is the retail price of nontradable goods, taking $w_{t}, r_{t}$ and $K_{t}^{P}$ as given. The first-order conditions are

$$
\begin{gathered}
z_{t} w_{t}=\eta\left(\frac{Y_{t}^{N}}{L_{t}^{N}}\right), \\
z_{t} r_{t}^{K}=(1-\eta)\left(\frac{Y_{t}^{N}}{K_{t}^{N}}\right),
\end{gathered}
$$

where $z_{t}=1 / P_{t}^{N}$ is defined as the unadjusted real exchange rate. 


\subsection{Distribution Sector}

The sale of physical units of nonoil tradable goods to consumers requires using $\gamma_{t}$ units of the nontradable good, which are spent in distribution services. This implies that the law of one price does not hold: the cost of distributing nonoil traded goods introduces a wedge between the producer and the consumer price of these goods. As in Burstein et al. (2003), the distribution sector is perfectly competitive so the retail price of tradable goods is equal to the marginal cost. This implies that

$$
P_{t}^{T}=1+\gamma_{t} P_{t}^{N}
$$

where $P_{t}^{T}$ is the retail price of tradable goods.

A significant fraction of distribution costs are assumed to consist of transportation costs, which are related negatively to access to (congested) infrastructure:

$$
\gamma_{t}=\gamma^{0}\left(\frac{K_{t}^{I}}{K_{t}^{P}}\right)^{-\varrho}
$$

where $\gamma^{0}>0$ and $\varrho \in(0,1)$.

\subsection{Households}

Consumption decisions follow a two-step process: households first determine the optimal path of total consumption over time, and then allocate that amount at each moment in time between spending on nonoil tradables and nontradables. Specifically, in the first stage the representative household chooses sequences of consumption, $C_{t+s}$, labor, $L_{t+s}$, capital, $K_{t+s+1}^{P}$, and debt, $D_{t+s+1}^{P}$, for $s=0,1, \ldots \infty$, and given $K_{t}^{P}$ and $D_{t}^{P}$, in order to maximize lifetime utility:

$$
U_{t}=\mathbb{E}_{t} \sum_{s=0}^{\infty} \Lambda^{s}\left\{\frac{\left[C_{t+s}\left(K_{t+s}^{I}\right)^{\eta_{I}}\right]^{1-\varsigma^{-1}}}{1-\varsigma^{-1}}-\frac{\eta_{L}}{1+\psi} L_{t+s}^{1+\psi}\right\},
$$

where $\mathbb{E}_{t}$ is the expectations operator, conditional on information available up to period $t, \Lambda \in(0,1)$ is a discount factor, $\varsigma>0$ the intertemporal elasticity of substitution in consumption, $\psi$ the inverse of Frisch elasticity of labor supply, and $\eta_{I}, \eta_{L}>0$ preference parameters. As in some recent contributions focusing on the dual nature of public goods, public capital interacts with consumption to generate direct utility benefits. ${ }^{6}$

\footnotetext{
${ }^{6}$ See Agénor (2008) and Chatterjee and Ghosh (2011). In the first contribution, the interaction between public capital and consumption operates through the public provision of health services.
} 
At the beginning of period $t$, firms receive from households the stock of capital (which can be freely reallocated across production sectors) that they acquired at date $t-1$. The stock of private capital evolves therefore according to

$$
K_{t}^{P}=\left(I_{t-1}^{P}\right)^{\varphi_{K}}\left(\frac{K_{t-1}^{I}}{K_{t-1}^{P}}\right)^{1-\varphi_{K}}+\left(1-\delta^{P}\right) K_{t-1}^{P}-\Gamma\left(K_{t}^{P}, K_{t-1}^{P}\right),
$$

where $I_{t}^{P}$ is private investment, which consists only of spending on tradables, $\delta^{P} \in(0,1)$ a constant rate of depreciation, $\varphi_{K} \in(0,1)$, and $\Gamma()$ an adjustment cost function. In a novel fashion, equation (13) captures a direct complementarity effect between private investment and public capital, by assuming that gross private investment must be combined with (congested) public capital to generate effective investment.

The capital adjustment cost function is specified as

$$
\Gamma\left(K_{t}^{P}, K_{t-1}^{P}\right)=0.5 \kappa\left(\frac{K_{t}^{P}}{K_{t-1}^{P}}-1\right)^{2} K_{t-1}^{P},
$$

where $\kappa>0$ is an adjustment cost parameter.

Households own both types of firms. Their net income consists of after-tax nonoil income, which is used to service their foreign debt, consume, invest, and pay lump-sum taxes, $T_{t}^{L}$; shortfalls in resources are offset by increases in foreign debt. Let $D_{t}^{P}$ denote household foreign-currency debt; the representative household's end-of-period budget constraint is thus given by

$$
D_{t+1}^{P}=\left(1+r_{t}^{W}\right) D_{t}^{P}-(1-\tau)\left(Y_{t}^{T}+z_{t}^{-1} Y_{t}^{N}\right)+C_{t}+I_{t}^{P}+T_{t}^{L}
$$

where $\tau \in(0,1)$ and $r_{t}^{W}$ is the interest rate that domestic agents face on world capital markets, which is defined later.

In the first stage of the optimization problem, households maximize (12) subject to (13)-(15). ${ }^{7}$ As shown in Appendix A, the first-order conditions are

$$
\begin{aligned}
\mathbb{E}_{t} C_{t+1}^{-\varsigma^{-1}} & =\frac{C_{t}^{-\varsigma^{-1}}}{\Lambda\left(1+r_{t}^{W}\right)} \mathbb{E}_{t}\left[\left(\frac{K_{t}^{I}}{K_{t+1}^{I}}\right)^{\eta_{I}\left(1-\varsigma^{-1}\right)}\right], \\
L_{t} & =\left[\frac{(1-\tau) w_{t} C_{t}^{-\varsigma^{-1}}}{\eta_{L}\left(K_{t}^{I}\right)^{-\eta_{I}\left(1-\varsigma^{-1}\right)}}\right]^{1 / \psi},
\end{aligned}
$$

\footnotetext{
${ }^{7}$ In solving this optimization problem I assume that the household does not internalize the complementarity effect. This is equivalent to setting $\varphi_{K}=1$ in (13).
} 


$$
\mathbb{E}_{t}\left\{\left[\kappa\left(\frac{K_{t+1}^{P}}{K_{t}^{P}}-1\right)+1\right]^{-1}\left[(1-\tau) r_{t+1}^{K}+1-\delta^{P}+\frac{\kappa}{2}\left(\frac{\Delta\left(K_{t+2}^{P}\right)^{2}}{\left(K_{t+1}^{P}\right)^{2}}\right)\right]\right\}=1+r_{t}^{W},
$$

together with the appropriate transversality conditions on $K_{t}^{P}$ and $D_{t}^{P}$. Equation (16) boils down to the standard Euler equation when $\eta_{I}=0$. Equation (17) defines labor supply, and (18), where $\Delta\left(K_{t+2}^{P}\right)^{2}=\left(K_{t+2}^{P}\right)^{2}-\left(K_{t+1}^{P}\right)^{2}$, equates the expected return on capital (net of marginal adjustment costs) with the world interest rate.

Consumption is a bundle of nonoil tradables and nontradables, $C_{t}^{T}$ and $C_{t}^{N}$ :

$$
C_{t}=\left(C_{t}^{N}\right)^{\theta}\left(C_{t}^{T}\right)^{1-\theta}
$$

where $\theta \in(0,1)$.

Nominal consumption spending is $P_{t}^{T} C_{t}^{T}+P_{t}^{N} C_{t}^{N}$, that is, using (10), $\left(1+\gamma_{t} P_{t}^{N}\right) C_{t}^{T}+$ $P_{t}^{N} C_{t}^{N}$. In the second stage of the optimization problem, the representative household therefore maximizes (19) subject to the static budget constraint

$$
C_{t}=\left(1+\gamma_{t} z_{t}^{-1}\right) C_{t}^{T}+z_{t}^{-1} C_{t}^{N}
$$

where real consumption is measured (consistent with (15)) in terms of the world price of nonoil tradables. The solution is given by

$$
\begin{gathered}
C_{t}^{N}=\theta z_{t} C_{t}, \\
C_{t}^{T}=\left(\frac{1-\theta}{1+\gamma_{t} z_{t}^{-1}}\right) C_{t}=(1-\theta)\left(\frac{z_{t}}{x_{t}}\right) C_{t},
\end{gathered}
$$

where $x_{t}=P_{t}^{T} / P_{t}^{N}$ is the "adjusted" (for distribution costs) real exchange rate. From (10),

$$
x_{t}=\frac{1+\gamma_{t} P_{t}^{N}}{P_{t}^{N}}=z_{t}+\gamma_{t}
$$

which implies, given (11), that the adjusted real exchange rate depends directly on the public-private capital ratio. ${ }^{8}$

\subsection{Government}

The government receives revenues from oil production, $T_{t}^{O}$, taxes on nonoil income, $T_{t}^{N O}$, as well as lump-sum taxes, $T_{t}^{L}$. It also receives interest income on the stock of foreigncurrency assets, $F_{t}$, held in a resource fund (if any), at the net interest rate $r_{t}^{F}$. Total

\footnotetext{
${ }^{8}$ Without distribution costs, the ratio $z_{t} / x_{t}$ in $(22)$ is of course unity.
} 
revenue, measured in foreign-currency terms, is thus given by

$$
T_{t}=T_{t}^{O}+T_{t}^{N O}+T_{t}^{L}+r_{t}^{F} F_{t}
$$

or equivalently

$$
T_{t}=P_{t}^{O} Y_{t}^{O}+\tau\left(Y_{t}^{T}+z_{t}^{-1} Y_{t}^{N}\right)+T_{t}^{L}+r_{t}^{F} F_{t}
$$

The government buys nonoil tradable and nontradable goods at producer prices; its purchases, measured in foreign-currency terms, are given by $G_{t}$, whose determination depends (as discussed later) on the fiscal rule in place. Government spending is allocated in fixed fractions to investment $I_{t}^{G}$ (measured in foreign-currency-terms) and consumption, $C_{t}^{G}$, which consists only of nontraded goods:

$$
\begin{gathered}
I_{t}^{G}=v^{G} G_{t}, \\
C_{t}^{G}=\left(1-v^{G}\right) z_{t} G_{t},
\end{gathered}
$$

where $v^{G} \in(0,1)$. Thus,

$$
G_{t}=I_{t}^{G}+z_{t}^{-1} C_{t}^{G}
$$

In turn, public investment is allocated in fixed proportions between spending on nontraded goods, $I_{t}^{G, N}$, and spending on nonoil traded goods, $I_{t}^{G, T}$ :

$$
I_{t}^{G, N}=v^{G, N} z_{t} I_{t}^{G}, \quad I_{t}^{G, T}=\left(1-v^{G, N}\right) I_{t}^{G}
$$

where $v^{G, N} \in(0,1)$. By implication,

$$
I_{t}^{G}=I_{t}^{G, T}+z_{t}^{-1} I_{t}^{G, N}
$$

The stock of public capital evolves according to

$$
K_{t}^{I}=\left(1-\delta^{G}\right) K_{t-1}^{I}+\varphi_{t-1} I_{t-1}^{G}
$$

where $\varphi_{t} \in(0,1)$ is an indicator of efficiency of spending on infrastructure and $\delta^{G} \in(0,1)$ is the depreciation rate. ${ }^{9}$

\footnotetext{
${ }^{9}$ This specification was initially proposed by Pritchett (2000), in a discussion of growth accounting, and first used in a formal macro/development setting by Agénor (2010). Araujo et al. (2016) adopt the same assumption.
} 
To capture absorption capacity constraints, the efficiency parameter is assumed to be negatively related with the ratio of public investment to public capital:

$$
\varphi_{t}=\varphi_{0}\left(\frac{I_{t}^{G}}{K_{t}^{I}}\right)^{-\varphi_{1}}
$$

where $\varphi_{0}, \varphi_{1}>0$. Thus, as investment (in proportion of the capital stock) increases, absorptive constraints tend to develop, possibly at an increasing rate $\left(\varphi_{1}>1\right)$; this, in turn, tends to slow the rate of public capital accumulation and mitigate the benefits of higher public investment. ${ }^{10}$

The government issues foreign-currency denominated debt, $D_{t}^{G}$, at the world interest rate $r_{t}^{W}$, to finance its deficit. The government's flow budget constraint is thus given by

$$
D_{t+1}^{G}=\left(1+r_{t}^{W}\right) D_{t}^{G}+G_{t}-T_{t}
$$

The nonresource primary balance, $B_{t}^{N O}$, is defined as

$$
B_{t}^{N O}=T_{t}^{N O}+T_{t}^{L}-G_{t}
$$

\subsection{Market-Clearing Conditions}

Total output, $Y_{t}$, measured in foreign-currency terms, can be defined as

$$
Y_{t}=Y_{t}^{T}+z_{t}^{-1} Y_{t}^{N}+P_{t}^{O} Y_{t}^{O}
$$

The market-clearing condition of the nontradable sector equates supply of nontradables to demand, consisting of purchases by households and the government, public investment, and distribution costs:

$$
Y_{t}^{N}=C_{t}^{N}+C_{t}^{G}+I_{t}^{G, N}+\gamma_{t} C_{t}^{T}
$$

The labor market equilibrium condition is given by

$$
L_{t}=L_{t}^{N}+L_{t}^{T}
$$

\footnotetext{
${ }^{10}$ By contrast, in Berg et al. (2013) and related contributions, the efficiency parameter is subject to a threshold effect related to the level of public investment. An alternative approach, as in van der Ploeg (2012) and van den Bremer and van der Ploeg (2013), would be to assume that public investment is subject to adjustment costs, which fall with the amount invested.
} 
The capital market equilibrium condition indicates that the stock of capital acquired last period is allocated today across the two production sectors:

$$
K_{t-1}^{P}=K_{t}^{T}+K_{t}^{N}
$$

In the benchmark case, and some subsequent experiments, no resources are accumulated in the sovereign wealth fund; thus

$$
F_{t+1}=F_{t}=0 \text {. }
$$

Combining the household and government budget constraints, together with the equilibrium condition (36) and the accumulation rule (39), yields the familiar debt accumulation equation (or equivalently, the negative of the current account balance):

$$
\begin{gathered}
D_{t+1}-F_{t+1}=\left(1+r_{t}^{W}\right) D_{t}-\left(1+r_{t}^{F}\right) F_{t}+C_{t}^{T} \\
+I_{t}^{G, T}+I_{t}^{P}-Y_{t}^{T}-P_{t}^{O} Y_{t}^{O},
\end{gathered}
$$

where $D_{t}=D_{t}^{P}+D_{t}^{G}$ denotes total foreign liabilities.

\subsection{World Interest Rate}

The interest rate earned by the country's sovereign fund, $r_{t}^{F}$, is set equal to the constant risk-free world interest rate, $r^{W, R}$ :

$$
r_{t}^{F}=r^{W, R}
$$

By contrast, the market cost of foreign borrowing depends on the world risk-free rate and a risk premium, $P R_{t}$ :

$$
r_{t}^{W}=\left(1+r^{W, R}\right)\left(1+P R_{t}\right)-1 .
$$

The premium itself is positively related to the country's government debt-tradable output ratio:

$$
P R_{t}=\left(\frac{D_{t}^{G}}{Y_{t}^{T}+P_{t}^{O} Y_{t}^{O}}\right)^{p r_{1}},
$$

where $p r_{1}>0$. Thus, all else equal, an increase in oil output lowers the risk premium through a reduction in the debt-tradable output ratio. 
A competitive equilibrium in this framework consists of sequences of allocations $\left\{C_{t}^{N}\right.$, $\left.C_{t}^{T}, I_{t}^{P}, D_{t}, F_{t}, L_{t}^{N}, L_{t}^{T}, K_{t}^{P}, K_{t}^{N}, K_{t}^{T}, G_{t}\right\}_{t=0}^{\infty}$, final good and factor input prices, $\left\{P_{t}^{N}, P_{t}^{T}\right.$, $\left.w_{t}, r_{t}^{K}\right\}_{t=0}^{\infty}$, such that, taking as given $K_{-1}^{P}, K_{-1}^{I}, D_{-1}, F_{-1}$, the exogenous processes $\left\{P_{t}^{O}, Y_{t}^{O}\right\}_{t=0}^{\infty}$, constant policy parameters $\tau, v^{G}$, and $v^{G, N}$, and constant public debt,

a) $\left\{C_{t}, C_{t}^{N}, C_{t}^{T}, L_{t}, I_{t}^{P}, D_{t}^{P}, K_{t}^{P}\right\}_{t=0}^{\infty}$ solve the representative household's optimization problem;

b) $\left\{L_{t}^{N}, K_{t}^{N}\right\}$ solve the nontradable good firm's optimization problem;

c) $\left\{L_{t}^{T}, K_{t}^{T}\right\}$ solve the nonoil tradable good firm's optimization problem;

d) the government sets a sequence of spending $\left\{G_{t}\right\}_{t=0}^{\infty}$, its components $\left\{C_{t}^{G}, I_{t}^{G}\right\}_{t=0}^{\infty}$, and a sequence of lump-sum taxes $\left\{T_{t}^{L}\right\}_{t=0}^{\infty}$, so that its flow and lifetime budget constraints are satisfied; and

e) market-clearing conditions for nontradable goods, labor, private capital, and nonoil tradable goods (equations (36), (37), (38), and (40), respectively) are satisfied.

\section{Steady State and Log-Linearization}

The steady-state equilibrium is characterized in Appendix B. Most of the equilibrium conditions are standard; in particular, from (18) the rental rate of capital is equal to $(1-\tau) \tilde{r}^{K}=\tilde{r}^{W}+\delta^{P}$, whereas from (13) and (14) private investment is equal to $\tilde{I}^{P}=\delta^{P} \tilde{K}^{P}$ when $\varphi_{K}=1 .^{11}$ And from the Euler equation (16), because the equilibrium stock of public capital is constant, the steady-state world interest rate is given by the standard expression $r^{W}=\Lambda^{-1}-1$. At the same time, as can be inferred from from (26) and (31), the steady-state public capital stock is $\tilde{K}^{I}=\varphi v^{G} \tilde{G} / \delta^{G}$.

The model is log-linearized in Appendix C. For convenience, and because they matter for specifying the fiscal rules that are studied later on, some equations pertaining to fiscal variables are reported here. Specifically, the log-linearized equations for total revenues (24) and the government budget constraint (33) with constant debt are given by

$$
\tilde{T} \hat{T}_{t}=\tilde{T}^{O} \hat{T}_{t}^{O}+\tilde{T}^{N O} \hat{T}_{t}^{N O}+\tilde{T}^{L} \hat{T}_{t}^{L}+\left(1+\tilde{r}^{F}\right) \tilde{F}\left(\hat{r}_{t}^{F}+\hat{F}_{t}\right)-\tilde{F} \hat{F}_{t}
$$

\footnotetext{
${ }^{11}$ In what follows steady-state values are denoted by tildes without time script, whereas percentage point deviations for interest rates and log-deviations for the other variables are denoted with a caret.
} 


$$
\tilde{T} \hat{T}_{t}=\left(1+\tilde{r}^{W}\right) \tilde{D}^{G} \hat{r}_{t}^{W}+\tilde{G} \hat{G}_{t} .
$$

These equations can be combined and solved for either lump-sum taxes, $\hat{T}_{t}^{L}$, or government spending, $\hat{G}_{t}$, depending on the fiscal rule in place (which also determines changes in assets held in the sovereign fund, $\hat{F}_{t}$ ).

For later convenience, the log-linearized equation for the nonoil primary balance is

$$
\tilde{B}^{N O} \hat{B}_{t}^{N O}=\tilde{T}^{N O} \hat{T}_{t}^{N O}+\tilde{T}^{L} \hat{T}_{t}^{L}-\tilde{G} \hat{G}_{t} .
$$

\section{Parameterization}

To understand the likely impact of an oil windfall on low-income countries the model is parameterized for a "typical" poor country that has recently begun to produce oil, whose reserves will take only a few decades for depletion, and has not yet accumulated substantial financial assets in a sovereign fund. Data sources include the World Bank's African Development Indicators database, the IMF's World Economic Outlook (WEO) database, as well as parameter estimates from various published papers.

For households, the intertemporal discount factor is set at 0.898 , based on the estimates of the real interest rate and the depreciation rate of private capital provided below. The intertemporal elasticity of substitution, $\varsigma$, is set at 0.2 , in line with the evidence for lowincome countries reported in Agénor and Montiel (2015, Chapter 11). The Frisch elasticity of labor supply is set at 0.125 (so that $\psi=8$ ) to capture a fairly inelastic supply of labor. This is a fairly reasonable assumption for low-income countries. The preference parameter $\eta_{L}$ is set at a fairly low value, 0.14 . The share of nontradables in total consumption, $\theta$, is set at 0.55, in line for instance with Pieschacón (2012) and Rabanal and Tuesta (2013). The elasticity $\eta_{I}$ is set initially at a relatively low value, 0.08 .

The rate of depreciation of private capital, $\delta^{P}$, is set at 0.045 , which is consistent with some of the values reported by $\mathrm{Bu}$ (2006) for Sub-Saharan African countries. The parameter that measures the strength of adjustment costs to private capital is set at a high level, $\kappa=25$, to match a slow response of private investment to shocks. This is the same value used in Berg et al. (2013). The direct complementarity effect of public capital on private investment is assumed to be initially strong; accordingly, $\varphi_{K}=0.5$. 
For the oil sector, the degree of persistence in production, $\rho_{Y^{O}}$, is computed such that at half-life 50 percent of the oil reserves are still left in the ground. If proven oil reserves are expected to last 30 years, the formula yields $\left(\rho_{Y^{O}}\right)^{15}=0.5$, or equivalently $\rho_{Y^{O}}=0.955$. For oil prices, the degree of persistence is set at $\rho_{P^{O}}=0.93$ and the standard deviation of the nonsystematic shock $\epsilon_{t}^{P^{O}}$ at 0.25 , as in Maliszewski (2009).

For the nonoil sector, elasticities of production with respect to labor, $\beta$ and $\eta$, are set equal to 0.6 and 0.7 , respectively, to capture the fact that production in the nontradable sector is relatively more labor intensive $(\eta>\beta)$. These values are consistent with the range of estimates of the share of labor income for developing countries obtained by Guerriero (2012) for instance. The evidence on the strength of learning-by-doing effects in tradable activities is somewhat ambiguous (see Syverson (2011)); consequently, the elasticity of the productivity factor in the tradable sector with respect to the share of the labor force engaged in that sector, $\nu_{T}$, is kept at a fairly low value, 0.03 . The elasticities with respect to public capital, $\omega_{N}$ and $\omega_{T}$, are set initially at the same value in both sectors, 0.17 , which corresponds to the long-run value estimated through meta-regression analysis by Bom and Ligthart (2014, Table 4) for core public capital.

In the distribution sector, the sensitivity of distribution costs with respect to the public-private capital ratio, $\varrho$, is set at 4 , to capture a situation where the lack of access to infrastructure has significant marginal effects on these costs. The initial value of the distribution cost parameter, $\gamma$, is set at 0.5, as in Burnside et al. (2006) and Oviedo and Singh (2013) for instance.

Regarding the government, the nonoil tax rate, $\tau$, is set equal to the average tax revenue-to-GDP ratio calculated by Baldacci et al. (2004, Table 1) for a group of 39 low-income countries, 15.1 percent. The initial ratio of noninterest spending in GDP, $G / Y$, is set equal to 17.1 percent to capture an initial position of fiscal imbalance. Based on an estimate of debt service (itself calculated from values of $D^{G}$ and $r^{W}$ reported next), the steady-state solution of the government overall fiscal balance (33), which gives $\tilde{T}=\tilde{r}^{W} \tilde{D}^{G}+\tilde{G}$, can be used to calibrate the initial value of lump-sum taxes, $\tilde{T}^{L}$. The initial share of infrastructure investment in government spending, $v^{G}$, is set at 0.114 , or equivalently 1.9 percent of GDP, a value consistent with the range of estimates of investment shares reported in Foster and Briceño-Garmendia (2010) for Sub-Saharan Africa. 
The parameter that captures the allocation of investment in infrastructure to nontraded goods, $v^{G, N}$, is set at 0.62 , within the range of estimates of the share of nontradables in total investment for Côte d'Ivoire, Gabon, Ghana, and Uganda reported by Bems (2008, Table 8). Using the average value for the 30 Sub-Saharan African countries (excluding South Africa) in the sample compiled by Dabla-Norris et al. (2012), the efficiency parameter for public investment, $\varphi$, is set at $0.37 .{ }^{12}$ The parameter $\varphi_{1}$ is set at the low value of 0.05 initially, which implies that $\varphi_{0}$, which is solved for residually, is equal to 0.33 . The rate of depreciation of public capital, $\delta^{G}$, is set at 0.035 , in line with Agénor et al. (2008).

Government debt as a share of GDP, $D^{G} / Y$, is set equal to 23.7 percent, which is equal to the ratio of external debt to GDP for Sub-Saharan Africa in 2010 reported in the WEO database. Thus, all public debt is assumed to result from foreign borrowing. From the estimates compiled by Boyce and Ndikumana (2012, Table 1) for 33 countries in SubSaharan Africa, the average stock of private capital flight in the same year represented 78.7 percent of GDP. Thus, the economy's net external debt, as a share of GDP, can be calibrated at $23.7-78.7=-55.0$ percent. By this metric, in the initial equilibrium the country is a net creditor to the rest of the world. However, due to market imperfections only the public debt matters in the determination of the risk premium.

The world risk-free interest rate (in foreign-currency terms), $r^{W, R}$, is set initially at 0.017, which corresponds to the difference between recent averages on nominal yields on U.S. treasury 30-year bonds and an average rate of U.S. inflation of 2.0 percent. To estimate the country risk premium, the spread on sovereign bonds issued by Kenya on international financial markets is used. Recent averages on nominal yields on 30-year sovereign bonds issued by that country is 13.3 percent; the risk premium (in foreigncurrency terms) can thus be calculated as $[(1+0.113) /(1+0.017)]-1=0.094 .{ }^{13}$ This also implies that the household discount factor is equal to $1 /(1+0.113)=0.898$, as noted earlier. ${ }^{14}$ The elasticity of the risk premium with respect to the debt-tradable output ratio, $p r_{1}$, is set at 0.8 initially. Assets of the resource fund in proportion of GDP, $F / Y$,

\footnotetext{
${ }^{12}$ Dabla-Norris et al. (2012) define their metric on a range of 1 to 4 with an average value of 1.47 for the 30 countries; this value was simply divided by 4 to obtain an indicator between zero and unity.

${ }^{13}$ By way of comparison, van der Ploeg and Venables (2011) estimate from cross-country regressions a mean value for the interest rate spread of the order of 6.3 percent.

${ }^{14}$ This expression is derived from the steady-state relationship between the world interest rate and the discount factor, $\tilde{r}^{W}=\Lambda^{-1}-1$. See Appendix B.
} 
are set initially at a fairly low value, 0.01; the rate of return on these assets, as noted earlier, is set equal to the world risk-free rate.

Table 1 summarizes the benchmark parameter values whereas Table 2 presents initial steady-state values. The share of nontradable output in total output is equal to 59.5 percent, the share of oil production is 7.8 percent (and 39.6 percent of total government revenues), and the share of nonoil tradable output is 32.5 percent. These numbers are in line with those found in some other studies for developing countries (see for instance Pieschacón (2012, Table 2)). The rate of return on private capital is 17.8 percent and the private capital-output ratio is about 2 , consistent also with the evidence for developing countries (see World Bank (2013, Chapter 1)). Private consumption represents 75.7 percent of output and private investment is 11.7 percent, the latter in line with the low values observed in poor countries. Government consumption accounts for 20 percent of output and public investment (as noted earlier) is 1.9 percent. The nonresource primary balance is in surplus initially, at 6 percent of output. The initial public-private capital ratio is 9.2 percent, consistent with the assumption of an infrastructure-constrained economy.

\section{Alternative Fiscal Rules}

Suppose that the country considered cannot hedge against commodity price risk and experiences at period $t$ an unanticipated and temporary positive shock to the real price of oil, $P_{t}^{O} \cdot{ }^{15}$ The resource windfall corresponds therefore to the log-difference between actual oil revenues and their steady-state value, as defined in the log-linearized version of the model, weighted by their steady-state value, $\tilde{T}^{O} \hat{T}_{t}^{O}$. As a preliminary step to the analysis of the optimal allocation of resource windfalls, three alternative fiscal rules are considered. The first serves as the benchmark, whereas the other two serve to illustrate two extreme cases which, once combined, will help to define the intermediate case upon which an optimal rule can be derived.

With the cash transfer rule, the windfall is transferred entirely and directly to households (see for instance Baird et al. (2013)). Thus, there is no asset accumulation $\left(\hat{F}_{t}=0\right)$

\footnotetext{
${ }^{15}$ See Borensztein et al. (2013) for a discussion of the reasons why countries do not, or cannot, hedge against these risks. This assumption is particularly appropriate here given that we consider a low-income country with limited access to world capital markets.
} 
and lump-sum taxes are reduced by the amount of the windfall in oil revenues:

$$
\tilde{T}^{L} \hat{T}_{t}^{L}=-\tilde{T}^{O} \hat{T}_{t}^{O}
$$

with government spending $\hat{G}_{t}$ solved residually from the government budget constraint (45). Substituting (47) in equation (44) and setting $\hat{F}_{t}=\hat{r}_{t}^{F}=0$ yields $\tilde{T} \hat{T}_{t}=\tilde{T}^{N O} \hat{T}_{t}^{N O}$. In turn, substituting this result in (45) yields

$$
\tilde{G} \hat{G}_{t}=\tilde{T}^{N O} \hat{T}_{t}^{N O}-\left(1+\tilde{r}^{W}\right) \tilde{D}^{G} \hat{r}_{t}^{W}
$$

With the full spending rule, $\hat{F}_{t}=0$ again, oil revenues are spent entirely on both consumption and investment:

$$
\tilde{G} \hat{G}_{t}=\tilde{T}^{O} \hat{T}_{t}^{O},
$$

with lump-sum taxes $\hat{T}_{t}^{L}$ solved residually from the government budget constraint (45).

After substituting for $\hat{T}_{t}$ from (44), using (49), equation (45) yields

$$
\tilde{T}^{L} \hat{T}_{t}^{L}=-\tilde{T}^{N O} \hat{T}_{t}^{N O}-\left(1+\tilde{r}^{F}\right) \tilde{F}\left(\hat{r}_{t}^{F}+\hat{F}_{t}\right)+\tilde{F} \hat{F}_{t}+\left(1+\tilde{r}^{W}\right) \tilde{D}^{G} \hat{r}_{t}^{W}
$$

or, with $\hat{F}_{t}=\hat{r}_{t}^{F}=0$ :

$$
\tilde{T}^{L} \hat{T}_{t}^{L}=-\tilde{T}^{N O} \hat{T}_{t}^{N O}+\left(1+\tilde{r}^{W}\right) \tilde{D}^{G} \hat{r}_{t}^{W}
$$

With the full saving rule (or full asset accumulation), the log-linearized law of motion for the stock of assets is given by

$$
\tilde{F} \hat{F}_{t+1}=\left(1-\phi^{F}\right) \tilde{F} \hat{F}_{t}+\tilde{T}^{O} \hat{T}_{t}^{O}
$$

where $\phi^{F} \in(0,1)$ is a coefficient that measures a (small) management fee, levied on the stock of assets held in the sovereign fund. ${ }^{16}$ Deviations in government spending from its steady-state value are now limited to changes in the flow of interest income generated from the fund:

$$
\tilde{G} \hat{G}_{t}=\left(1+\tilde{r}^{F}\right) \tilde{F}\left(\hat{r}_{t}^{F}+\hat{F}_{t}\right)-\tilde{F} \hat{F}_{t}
$$

\footnotetext{
${ }^{16}$ With $\phi^{F}=0$, a temporary increase in external savings due to an oil windfall would lead to a permanent increase in the stock of external assets. A positive value of $\phi^{F}$ is necessary to eliminate the unit root in $F_{t}$ and to calculate the asymptotic variances that are needed later on.
} 
Because oil revenues are no longer a direct resource for the government, $\tilde{T}^{O} \hat{T}_{t}^{O}$ must be taken out of the definition of $\hat{T}_{t}$, implying therefore that equation (44) becomes

$$
\tilde{T} \hat{T}_{t}=\tilde{T}^{N O} \hat{T}_{t}^{N O}+\tilde{T}^{L} \hat{T}_{t}^{L}+\left(1+\tilde{r}^{F}\right) \tilde{F}\left(\hat{r}_{t}^{F}+\hat{F}_{t}\right)-\tilde{F} \hat{F}_{t}
$$

Substituting this result in the government budget constraint (45) and using (52) implies that lump-sum taxes are once again determined by (50).

The full spending experiment is consistent with the view, advocated in a number of recent contributions, that low-income countries should use resource windfalls to address their development needs. In contrast to some of these studies, however, the view here is that these development needs are not limited to infrastructure investment; poor countries also face pressing needs in terms of education and health services. Even though the supply of these services are not explicitly modeled, this is captured by assuming that resource windfalls are allocated to total government spending, as stated in (49). The full saving experiment corresponds to the so-called bird-in-hand policy: the government limits spending from a windfall to the stream of returns from accumulated financial assets (see Collier et al. (2010)). As reported in Table 1, the management fee, $\phi^{F}$, is set at a low value, 0.25 percent of the stock of assets, a number in line with current practices of international asset management companies. ${ }^{17}$

To illustrate the functioning of the model, an experiment consisting of a 10 percent temporary increase in $P_{t}^{O}$ is performed. Figure 1 reports the results obtained under the full spending rule. The oil revenue windfall leads to an immediate increase in public consumption and investment; the resulting increase in the demand for nontraded goods leads to a real appreciation. To maintain equilibrium in the labor market, the product wage (measured in terms of the price of nonoil traded goods) must increase. This increase, however, is less than proportional to the movement in the real exchange rate, implying that the product wage in the nontradable sector falls. There is therefore a shift on the supply side toward the production of nontradables at the expense of nonoil tradables. Despite the increase in the value of oil output, the contraction in the nonoil tradable sector is such that total tradable output falls; and given that public debt is constant, the risk premium on world capital markets rises through a higher debt-tradable output ratio.

\footnotetext{
${ }^{17}$ See the Sovereign Wealth Fund Institute website, http://www.swfinstitute.org/.
} 
The increase in the cost of borrowing tends to reduce (through the arbitrage condition with the rental rate of capital) private investment. The return to private capital also falls, thereby inducing households to save less and spend more today. Higher spending on nontradables magnifies the initial real appreciation. In addition, the increase in private consumption raises the demand for leisure and lowers labor supply. Total employment falls while at the same time workers are reallocated from the production of nonoil tradables to nontradables. At first, the drop in the former is smaller than the expansion of the latter, implying that nonoil output increases, and so do nonoil tax revenues. In turn, the increase in revenues fuels higher spending by the government and, despite the fall in the efficiency of public investment due to absorption constraints, the public capital stock begins to increase. This promotes production of both nonoil tradables and nontradables.

Over time, oil revenues and government spending fall gradually, whereas nonoil revenues follow an inverted $U$ shape that reflects the behavior of nonoil output. The initial appreciation is magnified at first, reflecting a sustained expansion (albeit at a decreasing marginal rate) in private consumption. However, the expansion in nontradable output, and the fact that the gradual increase in the stock of public capital tends to lower transportation costs, tend to mitigate the upward pressure on the real exchange rate. Because the increase in the risk premium is fairly persistent, private investment remains depressed for a while. And despite the recovery in labor supply (which inversely mirrors the behavior of consumption) the persistent drop in the private capital stock leads to a contraction in output of nontradables, whereas the gradual reversal in the behavior of the real exchange rate (which generates expenditure-switching effects), coupled with a sustained increase in the public-private capital ratio, benefit mostly productivity of private inputs and production in the traded good sector. Productivity in the traded goods sector rises also, through learning-by-doing externalities. At the same time, the increase in the public-private capital ratio raises gradually the marginal product of labor, thereby also contributing to the recovery in employment, and reduces distribution costs, which mitigates the effect of the shock on the (adjusted) real exchange rate. Over time, as public investment falls, its efficiency recovers. The increase in the public capital stock, through the direct complementarity effect discussed earlier, helps to stabilize the drop in private investment initially and to contribute to its recovery subsequently. 
The behavior of the model under the cash transfer displays similar properties as those described above. Dutch disease effects are weaker in the short run, given that public investment does not increase. The weaker appreciation of the real exchange rate mitigates the magnitude of the reallocation of resources from the tradable sector to the nontradable sector, as well as the expansion in production in the latter. As before there is a contraction in private investment and an increase in consumption, but they are both also mitigated.

With the full saving rule, assets held in the sovereign fund increase rapidly (as a share of output) and the interest income that they generate is used to finance both consumption and investment, in proportion of initial spending allocations. The increase in the cost of borrowing abroad leads to lower consumption today, thereby raising private savings and investment. The real exchange rate now depreciates on impact, and this induces downward pressure on the product wage (measured in terms of the price of nonoil traded goods) to maintain labor market equilibrium. This effect is magnified by the increase in labor supply, implying that the product wage in the nontradable sector increases by more than the product wage in the tradable sector. This would normally induce a reallocation of labor from the nontradable to the tradable sector. At the same time, however, the increase in private investment and in the private capital stock benefit mostly the nontradable sector, where it is a relatively scarce factor to begin with. This raises the marginal product of labor there sufficiently so for labor to flow to that sector and for output to expand. Thus, even though the policy entails a depreciation (in contrast to the full spending case), the net effect is still a shift in production toward nontradables. Over time, the contraction in household consumption is mitigated and so is the expansion of investment. ${ }^{18}$

The thrust of the foregoing analysis is that, under either a spending rule or a cash transfer rule, the model is capable of reproducing some of the key stylized facts associated with a resource windfall. The key difference with more standard models, of course, is the presence of public capital which affects the supply- and demand-sides of the economy through a variety of channels. In particular, although increases in public investment may help to fuel aggregate demand and magnify a real appreciation in the short run, over time the positive supply-side effects of public capital work in the opposite direction. Because

\footnotetext{
${ }^{18}$ The working paper version of this article discusses in more detail the behavior of the model under the cash transfer and the full saving rules.
} 
of its ability to reproduce these basic facts, the model provides a natural benchmark to study the main issue of interest in this paper - the optimal allocation of resource windfalls, possibly "in between" the pure spending, cash transfer, and saving rules discussed earlier.

\section{Optimal Allocation of Resource Windfalls}

Given dire infrastructure needs and significant constraints on absorption capacity, but also concerns about household welfare and macroeconomic volatility, what should be the optimal allocation of a resource windfall between spending today and spending tomorrow, through accumulation in a resource fund? As noted earlier, this issue is of great practical concern to a number of low-income countries, particularly those that are highly vulnerable to volatility and uncertainty of resource revenue as a result of a high degree of concentration of their exports. The analysis aims therefore to account for the revealed preferences of policymakers, in addition to pure welfare considerations.

Conceptually, this can be addressed by assuming that the government's goal is to allocate a fraction $\chi \in(0,1)$ of the oil windfall to a sovereign fund and a fraction $1-\chi$ to current spending, which includes infrastructure investment. With $\chi<1$, the government raises not only spending today but also all future spending by using some of the current windfall to increase its assets held in the sovereign fund.

Formally, the resource accumulation rule is now, instead of (51),

$$
\tilde{F} \hat{F}_{t+1}=\left(1-\phi^{F}\right) \tilde{F} \hat{F}_{t}+\chi \tilde{T}^{O} \hat{T}_{t}^{O}
$$

whereas the spending rule generalizes (52) to give

$$
\tilde{G} \hat{G}_{t}=(1-\chi) \tilde{T}^{O} \hat{T}_{t}^{O}+\left(1+\tilde{r}^{F}\right) \tilde{F}\left(\hat{r}_{t}^{F}+\hat{F}_{t}\right)-\tilde{F} \hat{F}_{t}
$$

The term $\tilde{T}^{O} \hat{T}_{t}^{O}$ must also now be replaced by $(1-\chi) \tilde{T}^{O} \hat{T}_{t}^{O}$ in defining total taxes in (44). Substituting the resulting expression for $\hat{T}_{t}$ in (45) and using (54), it can be established that lump-sum taxes are once again determined by (50).

Most existing contributions have focused on utility-based measures of social welfare, abstracting from other considerations that may be important for policymakers. ${ }^{19}$ The

\footnotetext{
${ }^{19}$ Maliszewski (2009) for instance discusses derivations of optimizing rules under various social welfare
} 
stability criterion that I propose in this paper is to determine $\chi$ so as to minimize a fundamental social loss function defined as a weighted geometric average of the volatility of private consumption - which is detrimental to welfare if households are risk averse - and the volatility of the nonresource primary balance, $\sigma_{C}^{\chi}$ and $\sigma_{B^{N O}}^{\chi}$, normalized with respect to the volatility indicators corresponding to the benchmark experiment (cash transfers), $\sigma_{C}^{B}$ and $\sigma_{B^{N O}}^{B}$ :

$$
\mathcal{L}_{t}^{F}(\chi)=\left(\frac{\sigma_{C}^{\chi}}{\sigma_{C}^{B}}\right)^{\mu}\left(\frac{\sigma_{B^{N O}}^{\chi}}{\sigma_{B^{N O}}^{B}}\right)^{1-\mu},
$$

where $\mu \in(0,1)$. Thus, if the government sets policy solely on the basis of household welfare (respectively fiscal stability) considerations, $\mu=1$ (respectively $\mu=0$ ).

An alternative stability criterion is to determine $\chi$ so as to minimize a generalized social loss function that involves a weighted average of the volatility of private consumption (as before) and a broader measure of macroeconomic volatility, defined in terms of a weighted average of the volatility of the nonoil primary balance and the volatility of the real exchange rate, with equal weights as a point of reference:

$$
\mathcal{L}_{t}^{G}(\chi)=\left(\frac{\sigma_{C}^{\chi}}{\sigma_{C}^{B}}\right)^{\mu}\left[\left(\frac{\sigma_{B^{N O}}^{\chi}}{\sigma_{B^{N O}}^{B}}\right)^{0.5}\left(\frac{\sigma_{z}^{\chi}}{\sigma_{z}^{B}}\right)^{0.5}\right]^{1-\mu},
$$

where again $\mu \in(0,1)$.

The positive (rather than purely normative) approach proposed here to measuring social welfare is aimed at addressing two distinct considerations. The first is household welfare, which in general is adversely affected by the volatility of private consumption. The second is either fiscal volatility or more generally macroeconomic volatility. The volatility of the nonoil primary balance (defined in (46)) aims to capture movements in fiscal variables that are not linked to fluctuations in oil prices, whereas movements in the real exchange rate are taken to capture changes in a key relative price, fluctuations in which are often viewed as a key symptom of macroeconomic instability.

The first panel of Table 3 shows the value of the fundamental loss function (55), calculated on the basis of (unconditional) asymptotic variances, for $\mu$ and $\chi$ both varying between 0 and 1 with a grid of 0.1 . The use of asymptotic variances means therefore that

functions and ad hoc rules, but his model has no productive public goods. The same issue arises in the analysis of Engel et al. (2013). van der Ploeg and Venables (2013) and van den Bremer and van der Ploeg (2013) account for public capital but continue to focus on utility-based measures of social welfare. 
the policymaker is concerned not only about volatility "today" but also about volatility "tomorrow" (in fact, into the indefinite future). The results show that while the function is decreasing in $\mu$ for $\chi$ given, it has a convex shape in $\chi$ for $\mu$ given. The reason is that, as shown in Figure 2, volatility of both consumption and the nonresource primary balance are convex in $\chi$. Intuitively, spending all the revenues associated with a windfall creates a lot of volatility in the economy. As $\chi$ increases, more of the windfall is saved; the reduction in today's spending tends at first to reduce that volatility. However, as $\chi$ continues to rise, the interest income from the assets held in the sovereign fund becomes larger, and this tends to raise spending over time - thereby increasing volatility once again. This effect is not symmetric, because the shock is temporary and the increase in spending associated with interest income (whose level depends also on the risk-free interest rate and the management fee paid on asset held in the sovereign fund) is more gradual than the reduction in spending initially associated with a higher $\chi$. In the present case this means less volatility in consumption but more volatility in the nonresource primary balance for high values of $\chi$, while the opposite holds with low values of $\chi$. Nevertheless, there is a fundamental dynamic volatility trade-off between spending now and spending later with respect to each volatility measure in the loss function.

The convexity of the loss function means that there is a value of $\chi$ for which the loss function is minimized. That value is shown in bold in the table. For $\mu=0.5$ for instance, which implies that the government attaches equal weight to consumption volatility and fiscal volatility, the optimal value of $\chi$ is also 0.5. Given the calibration, the higher the weight attached to consumption volatility (the higher $\mu$ is, or conversely, the lower the weight $1-\mu$ attached to fiscal volatility), the higher the share of the resource windfall that the government should save. These results are also illustrated in the three-dimensional diagram of Figure 3. In addition, the results show that the optimal policy is always better, in terms of overall volatility, than a pure cash transfer policy; the value of the loss function is always less than unity for the optimal $\chi$. The key reason for this is of course the fact that the policy has no direct effect on access to public services.

The grid of 0.1 used in the first panel of Table 3 is sufficient to illustrate the main point of the analysis. Of course, a more refined grid would give a more precise value of $\chi$. The second panel illustrates this case when $\chi$ varies between 0.4 and 0.5 , by intervals 
of 0.01 . The results show again that, as $\mu$ increases, the optimal value of $\chi$ also rises.

The third panel of Table 3 shows the optimal $\chi$ when the generalized loss function (56), is used, again with a grid of 0.1 . The results show that at low values of $\mu$ the optimal allocation parameter is now higher, compared to the first panel, because of concerns with real exchange rate volatility. Again, a finer grid would provide more precise values, especially for the cases where the choice of $\chi$ appears to be the same as with the fundamental loss function (for instance, for $\mu=0.6$ to 1.0). At this stage, however, the intuition is fairly clear. In the same vein, changing the relative weights attached to fiscal volatility and real exchange rate volatility is a rather straightforward exercise, which would not change the fundamental intuition of the methodology proposed here.

It is worth noting that, in the case of a negative shock, the intuition is of course symmetric, with $\chi$ representing now the proportion of the resources that are taken out of the sovereign fund - assuming, of course, that the fund is sufficiently capitalized to begin with. With small withdrawals ( $\chi$ low) the adverse shock creates a lot of volatility, in particular through a concomitant contraction in government spending. As $\chi$ increases (more and more resources previously saved are withdrawn from the fund), the adverse effect of the initial shock on spending is mitigated and volatility decreases at first. But as $\chi$ continues to rise and public outlays increase, volatility starts increasing again - at a slower rate now, given that (all else equal) the interest income generated by the lower level of assets held in the sovereign fund becomes smaller. Thus, the volatility curve takes again the same convex shape as shown in Figure 2.

\section{Sensitivity Analysis}

To assess the robustness of the results established in the previous sections, changes in several key parameters and model specification were considered: tighter absorption constraints; a higher elasticity of output to public infrastructure; an alternative specification of the risk premium on world capital markets; an investment-biased spending rule; imperfect mobility of physical capital across sectors; and public-private sharing of resource revenues. Detailed results of these experiments are reported in the working paper version of this article. They show, in particular, that a higher incidence of absorption constraints 
(or equivalently a weaker ability to design and manage investment projects) implies that when public investment increases at higher rates efficiency falls, thereby mitigating the increase in the public capital stock and making output, private consumption, and other macroeconomic variables less volatile. Thus, all else equal, a higher incidence of absorption constraints implies a lower optimal $\chi$. A higher degree of efficiency of public investment, $\varphi$, magnifies the supply-side effects of an increase in public investment and mitigates over time the volatility of the real exchange rate and consumption; this also leads to a lower optimal $\chi$.

Another experiment involved raising simultaneously the share of government spending allocated to infrastructure investment, $v^{G}$. This investment-biased spending rule is more realistic, and also perhaps more feasible politically, than a policy involving spending the interest income from assets held in the sovereign fund only on infrastructure, given that, as noted earlier, low-income countries face not only severe infrastructure needs but are also confronted with high demands on other components of spending, especially related to human development. As can be expected, the optimal value of $\chi$ is lower than in the benchmark case, given that a higher public capital stock mitigates the volatility of relative prices and consumption.

By and large, the sensitivity analysis confirms the key result highlighted earlier: the optimal choice of $\chi$ internalizes the dynamic trade-off associated with saving today, and spending tomorrow, the resources associated with a resource windfall. While changes in structural parameters and model specification do affect (as can be expected) the slope of that trade-off, especially those that alter the supply-side effects of public capital, they do not affect the fundamental result of the analysis - the existence of a U-shape relationship between volatility and the share of the windfall saved. ${ }^{20}$

\footnotetext{
${ }^{20}$ Another set of experiments would involve switching off one by one each of the four channels through which public capital operates (utility benefits, interaction with private investment in the formation of private capital, endogenous distribution costs, and endogenous efficiency of public investment). While the results, which are not reported here to save space, indicate that these channels do affect the slope of the dynamic trade-off associated with commodity price shocks, they also show that they do not affect either the fundamental insights of the analysis.
} 


\section{Concluding Remarks}

The main results of this paper were summarized in the introduction; in these concluding remarks it is more fruitful to consider two issues - the solution technique used, and possible model extensions.

The paper uses a DSGE framework to study the effects of temporary commodity price shocks. Even though these shocks can be persistent, entailing therefore prolonged transitional dynamics, they do not have long-run effects. As a result, only fluctuations around the steady-state equilibrium are analyzed. Yet, the fact that public capital exerts supply-side effects means that even temporary shocks could have permanent level effects, implying therefore that the steady state could change following these shocks.

Even though in the present setting changes across steady states are not accounted for, it is important to take into account the supply-side effects of productive public expenditures. The reason is that these effects matter from the perspective of mitigating volatility as well: they tend to offset the demand-side effects associated with the impact of the windfall on consumption and investment, and may therefore have a substantial impact on the volatility of the real exchange rate - and by implication the distribution of output and expenditure. Put differently, accounting for the transitional effects of productive public investment is important to discuss the short-run stabilization issue considered in the paper, even though the longer-run implications of this investment on the steady-state equilibrium are not explicitly accounted for.

Another issue relates to the fact that the paper uses a first-order log-linearization to solve the model. It is now well established that first-order approximations are insufficient in some cases, especially for conducting utility-based welfare analysis or when studying the dynamics of asset prices. In such cases, second- and higher-order approximations may be more accurate. At the same time, there are good reasons to believe that a first-order approximation may be a reasonable approach in the present case. First, only small shocks are considered, implying limited deviations from the initial steady state. Second, there are no asset demand equations and no asset prices in the model; the fact that the riskiness of an asset may be related to the variance of the underlying shocks is not a concern. Third, the paper focuses directly on asymptotic variances, not expected welfare, in defining the 
policy criterion; the degree of curvature of the utility function (which militates in favor of higher-order approximations) does not play a direct role in that regard. Fourth, higherorder approximation techniques remain difficult to implement with models (like this one) that are relatively large - the so-called "curse of dimensionality" problem. Nevertheless, even though it still remains to be seen if these techniques work for larger models, future research on managing resource windfalls should address both issues of switches in steady states and nonlinearities.

Future research could also consider various extensions of the model. In particular, it would be worth extending the analysis to consider yet more rules for putting resources into, and pulling resources out, of the sovereign fund than those considered in this paper. For instance, instead of assuming (as was done here) that interest income only is transferred to the government budget, it could be assumed that all commodity-related resources are allocated to the sovereign fund, and that a fraction of total fund assets (interest and principal) is withdrawn each period. Formally, the accumulation and spending rules (in levels) would then take the form $F_{t+1}=\left(1-\phi^{F}\right) F_{t}+T_{t}^{O}$, with $G_{t}=\lambda\left(1+r_{t}^{F}\right) F_{t}$ and $\lambda>0$. The issue then would be to solve for the optimal value of $\lambda$.

Another fruitful extension would be to develop a full political economy framework to provide stronger microfoundations for the loss function used-based, as argued earlier, on revealed (policy) preferences - not only in terms of the variables used but also the relative weight $\mu$ of each objective in that function. For instance, fiscal and macroeconomic volatility could create a potential (electoral) cost for the incumbent; but voters could also dislike consumption volatility and this could be internalized by the incumbent.

However, while using alternative solution techniques and extending the analytical framework along the lines described above could be valuable in their own right, it is not clear that they would affect the basic intuition and the fundamental methodological contribution of this paper - the U-shape nature of the dynamic volatility trade-off that fiscal authorities must face when choosing how to manage resource windfalls. 


\section{References}

Agénor, Pierre-Richard, "Health and Infrastructure in a Model of Endogenous Growth," Journal of Macroeconomics, 30 (December 2008), 1407-22.

—, "A Theory of Infrastructure-led Development," Journal of Economic Dynamics and Control, 34 (May 2010), 932-50.

—, Public Capital, Growth and Welfare, Princeton University Press (Princeton, New Jersey: 2012).

Agénor, Pierre-Richard, Nihal Bayraktar, and Karim El Aynaoui, "Roads Out of Poverty? Assessing the Links between Aid, Public Investment, Growth, and Poverty Reduction," Journal of Development Economics, 86 (June 2008), 277-95.

Agénor, Pierre-Richard, and Peter J. Montiel, Development Macroeconomics, 4th ed., Princeton University Press (Princeton, New Jersey: 2015).

Araujo, Juliana, Bin Li, Marcos Poplawski-Ribeiro, and Luis F. Zanna, "Current Account Norms in Natural Resource Rich and Capital Scarce Economies," Journal of Development Economics, 120 (May 2016), 144-56.

Baird, Sarah, Francisco H. G. Ferreira, Berk Özler, and Michael Woolcock, "Relative Effectiveness of Conditional and Unconditional Cash Transfers for Schooling Outcomes in Developing Countries," Systematic Review No. 8, the Campbell Collaboration (September 2013).

Baldacci, Emanuele, Arye L. Hillman, and Naoko C. Kojo, "Growth, Governance, and Fiscal Policy Transmission Channels in Low-Income Countries," European Journal of Political Economy, 20 (June 2004), 517-49.

Baunsgaard, Thomas, Mauricio Villafuerte, Marcos Poplawski-Ribeiro, and Christine Richmond, "Fiscal Frameworks for Resource Rich Developing Countries," Staff Discussion Note 12/04, International Monetary Fund (May 2012).

Bems, Rudolfs, "Aggregate Investment Expenditures on Tradable and Nontradable Goods," Review of Economic Dynamics, 11 (October 2008), 852-83.

Berg, Andrew, Rafael Portillo, Shu-Chun S. Yang, and Luis-Felope Zanna, "Public Investment in Resource-Abundant Developing Countries," IMF Economic Review, 61 (March 2013), 92-129.

Bom, Pedro R., and Jenny E. Ligthart, "What Have we Learned from Three Decades of Research on the Productivity of Public Capital?," Journal of Economic Surveys, 28 (December 2014), 889-916.

Borensztein, Eduardo, Olivier Jeanne, and Damiano Sandric, "Macro-Hedging for Commodity Exporters," Journal of Development Economics, 101 (March 2013), 105-16.

Boyce, James K., and Léonce Ndikumana, "Capital Flight from Sub-Saharan African Countries: Updated Estimates, 1970-2010," Research Report, University of Massachusetts Amherst (October 2012).

$\mathrm{Bu}$, Yisheng, "Fixed Capital Stock Depreciation in Developing Countries: Some Evidence from Firm Level Data," Journal of Development Studies, 42 (December 2006), 881-901. 
Burnside, Craig, Martin Eichenbaum, and Sergio Rebelo, "Government Finance in the Wake of Currency Crises," Journal of Monetary Economics, 53 (April 2006), 401-40.

Burstein, A., Neves, J., Sergio Rebelo, "Distribution Costs and Real Exchange Rate Dynamics during Exchange-Rate-Based Stabilizations," Journal of Monetary Economics, 50 (September 2003), 1189-214.

Chatterjee, Santanu, and Sugata Ghosh, "The Dual Nature of Public Goods and Congestion," Canadian Journal of Economics, 44 (November 2011), 1471-96.

Collier, Paul, Frederick van der Ploeg, Michael Spence, and Anthony J. Venables, "Managing Resource Revenues in Developing Economies," IMF Staff Papers, 51 (April 2010), 84-118.

Dabla-Norris, Era, Jim Brumby, Annette Kyobe, Zac Mills, and Chris Papageorgiou, "Investing in Public Investment: An Index of Public Investment Efficiency," Journal of Economic Growth, 17 (September 2012), 235-66.

Engel, Eduardo, Christopher Neilson, and Rodrigo Valdés, "Chile's Fiscal Rule as Social Insurance," in Fiscal Policy and Macroeconomic Performance, ed. by Luis F. Céspedes and Jordi Galí, Central Bank of Chile (Santiago: 2013).

Foster, Vivien, and Cecilia Briceño-Garmendia, eds., Africa's Infrastructure: A Time for Transformation, World Bank (Washington, D.C.: 2010).

Geiregat, Chris, and Susan Yang, "Too Much of a Good Thing?," Finance and Development, 50 (September 2013), 8-11.

Gelb, Allan H., "Economic Diversification in Resource-Rich Countries," in Beyond the Curse: Policies to Harness the Power of Natural Resources, ed. by R, Arezki, T. Gylfason, and A. Sy, International Monetary Fund (Washington DC: 2011).

Guerriero, Marta, "The Labour Share of Income around the World: Evidence from a Panel Dataset," Working Paper No. 32/12, Institute for Development Policy and Management (March 2012).

Lundgren, Charlotte J., Alun H. Thomas, and Robert C. York, Boom, Bust, or Prosperity? Managing Sub-Saharan Africa's Natural Resource Wealth, International Monetary Fund (Washington DC: 2013).

Maliszewski, Wojciech, "Fiscal Policy Rules for Oil-Producing Countries: A WelfareBased Assessment," Working Paper No. 09/126, International Monetary Fund (June 2009).

Oviedo, P. Marcelo, and Rajesh Singh, "Investment composition and International Business Cycles," Journal of International Economics, 89 (January 2013), 79-95.

Pieschacón, Anamaría, "The Value of Fiscal Discipline in Oil-Exporting Countries," Journal of Monetary Economics, 59 (April 2012), 250-68.

Pritchett, Lant, "The Tyranny of Concepts: CUDIE (Cumulated, Depreciated, Investment Effort) Is Not Capital," Journal of Economic Growth, 5 (December 2000), 361-84.

Rabanal, Pau, and Vicente Tuesta, "Nontradable Goods and the Real Exchange Rate," Open Economies Review, 24 (July 2013), 495-535.

Sy, Amadou N. R., "First Borrow," Finance and Development, 50 (June 2013), 52-54.

Syverson, Chad, "What Determines Productivity?," Journal of Economic Literature, 49 (June 2011), 326-65. 
Torvik, Ragnar, "Learning by Doing and the Dutch Disease," European Economic Review, 45 (February 2001), 285-306.

van den Bremer, Ton S., and Frederick van der Ploeg, "Managing and Harnessing Volatile Oil Windfalls," IMF Economic Review, 61 (April 2013), 130-67.

van der Ploeg, Frederick, "Natural Resources: Curse or Blessing?," Journal of Economic Literature, 49 (June 2011), 366-410.

_, "Bottlenecks in Ramping Up Public Investment," International Tax and Public Finance, 19 (August 2012), 509-38.

van der Ploeg, Frederick, and Anthony J. Venables, "Harnessing Windfall Revenues: Optimal Policies for Resource-Rich Developing Economies," Economic Journal, 121 (March 2011), 1-30.

—_, "Absorbing a Windfall of Foreign Exchange: Dutch Disease Dynamics," Journal of Development Economics, 103 (July 2013), 229-43.

World Bank, Capital for the Future: Saving and Investment in an Interdependent World, Global Development Horizons Report (Washington DC: 2013). 
Table 1

Parameterization: Benchmark Case

\begin{tabular}{|c|c|c|}
\hline Parameter & Value & Description \\
\hline \multicolumn{3}{|l|}{ Households } \\
\hline$\Lambda$ & 0.898 & Discount factor \\
\hline$\varsigma$ & 0.2 & Intertemporal elasticity of substitution \\
\hline$\eta_{L}$ & 0.14 & Preference parameter, labor in utility function \\
\hline$\eta_{I}$ & 0.08 & Preference parameter, public capital \\
\hline$\psi$ & 8 & Inverse of Frisch elasticity of labor supply \\
\hline$\theta$ & 0.55 & Share of nontradables in private consumption \\
\hline$\kappa$ & 25 & Adjustment cost parameter, private investment \\
\hline$\varphi_{K}$ & 0.5 & Strength of complementarity effect, private investment \\
\hline$\delta^{P}$ & 0.045 & Depreciation rate, private capital \\
\hline \multicolumn{3}{|l|}{ Oil production } \\
\hline$\rho_{Y^{O}}$ & 0.955 & Persistence parameter, oil output \\
\hline$\rho_{P O}$ & 0.93 & Persistence parameter, world oil price \\
\hline \multicolumn{3}{|c|}{ Nonoil production } \\
\hline$\beta, \eta$ & $0.6,0.7$ & Labor shares, tradable and nontradable sectors \\
\hline$\nu_{T}$ & 0.03 & Strength of learning-by-doing effect, tradable sector \\
\hline$\omega_{N}, \omega_{T}$ & 0.17 & Elasticity of output wrt public capital \\
\hline \multicolumn{3}{|c|}{ Distribution cost } \\
\hline \multicolumn{3}{|l|}{ Government } \\
\hline$\tau$ & 0.151 & Nonoil revenue ratio \\
\hline$\psi^{G}$ & 0.171 & Share of total government spending in output \\
\hline$v^{G}$ & 0.114 & Share of spending on infrastructure investment \\
\hline$v^{G, N}$ & 0.62 & Share of infrastructure investment on nontraded goods \\
\hline$\varphi$ & 0.37 & Efficiency parameter, public investment \\
\hline$\varphi_{1}$ & 0.05 & Absorption constraint parameter, public investment \\
\hline$\delta^{G}$ & 0.035 & Depreciation rate, public capital \\
\hline$\phi_{F}$ & 0.0025 & Management fee on sovereign assets \\
\hline$\chi$ & 0,1 & Fraction of resource windfalls allocated to a sovereign fund \\
\hline$\mu$ & 0,1 & Importance of consumption volatility in government loss function \\
\hline \multicolumn{3}{|l|}{ Risk premium } \\
\hline$p r_{1}$ & 0.8 & Elasticity wrt the debt-tradable output ratio \\
\hline
\end{tabular}


Table 2

Initial Steady-State Values

(In percent of total output, unless otherwise indicated)

\begin{tabular}{cll}
\hline \hline Variable & Value & \multicolumn{1}{c}{ Description } \\
\hline \hline$Y^{O}$ & 0.078 & Oil output \\
$z^{-1} Y^{N}$ & 0.595 & Nontradable output \\
$Y^{T}$ & 0.325 & Nonoil tradable output \\
$L^{N} / L$ & 0.743 & Share of employment in nontradable sector \\
$C$ & 0.757 & Private consumption \\
$z^{-1} C^{N}$ & 0.820 & Consumption of nontradables \\
$C^{T}$ & 0.325 & Consumption of tradables \\
$I^{P}$ & 0.117 & Private investment \\
$K^{P}$ & 2.009 & Private capital stock \\
$I^{G}$ & 0.019 & Public investment \\
$G$ & 0.171 & Total government spending \\
$T^{N O}$ & 0.139 & Nonoil revenues \\
$T^{O}$ & 0.08 & Oil revenues \\
$T$ & 0.198 & Total revenues \\
$B^{N O}$ & 0.06 & Nonoil primary balance \\
$D^{G}$ & 0.237 & Government foreign liabilities \\
$D$ & -0.55 & Total foreign liabilities \\
$K^{I} / K^{P}$ & 0.092 & Public-private capital ratio (absolute value) \\
$r^{W, R}$ & 0.017 & World risk-free interest rate (in percent) \\
$P R$ & 0.094 & Risk premium (in percent) \\
$F$ & 0.01 & Assets in sovereign wealth fund \\
\hline \hline
\end{tabular}


Table 3

Optimal Allocation Rule, Fundamental and Generalized Loss Functions

\begin{tabular}{|c|c|c|c|c|c|c|c|c|c|c|c|}
\hline \multirow[b]{2}{*}{$\chi$} & \multicolumn{11}{|c|}{$\mu$} \\
\hline & 0.0 & \begin{tabular}{c|}
0.1 \\
\end{tabular} & \begin{tabular}{c|}
0.2 \\
\end{tabular} & $\begin{array}{l}0.3 \\
\end{array}$ & 0.4 & 0.5 & 0.6 & $\bar{~} 0.7$ & 0.8 & 0.9 & $\begin{array}{l}1.0 \\
\end{array}$ \\
\hline \multicolumn{12}{|c|}{ Fundamental Loss Function, $\chi$ varying between 0 and 1} \\
\hline 0.0 & 1.038 & 1.002 & 0.966 & 0.932 & 0.899 & 0.868 & 0.837 & 0.808 & 0.779 & 0.752 & 0.725 \\
\hline 0.1 & 0.950 & 0.913 & 0.877 & 0.843 & 0.811 & 0.779 & 0.749 & 0.720 & 0.692 & 0.665 & 0.639 \\
\hline 0.2 & 0.885 & 0.845 & 0.807 & 0.771 & 0.736 & 0.703 & 0.671 & 0.641 & 0.612 & 0.585 & 0.559 \\
\hline 0.3 & 0.850 & 0.804 & 0.760 & 0.719 & 0.679 & 0.643 & 0.608 & 0.575 & 0.543 & 0.514 & 0.486 \\
\hline 0.4 & 0.848 & 0.791 & 0.739 & 0.689 & 0.643 & 0.600 & 0.560 & 0.523 & 0.488 & 0.455 & 0.425 \\
\hline 0.5 & 0.880 & 0.809 & 0.744 & 0.685 & 0.630 & 0.579 & 0.533 & 0.490 & 0.451 & 0.415 & 0.382 \\
\hline 0.6 & 0.941 & 0.856 & 0.778 & 0.707 & 0.643 & 0.584 & 0.531 & 0.483 & 0.439 & 0.399 & 0.362 \\
\hline 0.7 & 1.028 & 0.928 & 0.838 & 0.757 & 0.684 & 0.617 & 0.558 & 0.504 & 0.455 & 0.411 & 0.371 \\
\hline 0.8 & 1.133 & 1.023 & 0.923 & 0.833 & 0.751 & 0.678 & 0.612 & 0.552 & 0.498 & 0.449 & 0.405 \\
\hline 0.9 & 1.253 & 1.134 & 1.026 & 0.928 & 0.839 & 0.759 & 0.687 & 0.622 & 0.562 & 0.509 & 0.460 \\
\hline 1.0 & 1.384 & 1.257 & 1.142 & 1.037 & 0.942 & 0.855 & 0.777 & 0.706 & 0.641 & 0.582 & 0.529 \\
\hline \multicolumn{12}{|c|}{ Fundamental Loss Function, $\chi$ varying between 0.40 and 0.50} \\
\hline 0.40 & 0.848 & 0.791 & 0.739 & 0.689 & 0.643 & 0.600 & 0.560 & 0.523 & 0.488 & 0.455 & 0.425 \\
\hline 0.41 & 0.850 & 0.792 & 0.738 & 0.688 & 0.641 & 0.597 & 0.556 & 0.519 & 0.483 & 0.450 & 0.420 \\
\hline 0.42 & 0.852 & 0.793 & 0.737 & 0.686 & 0.639 & 0.594 & 0.553 & 0.515 & 0.479 & 0.446 & 0.415 \\
\hline 0.43 & 0.854 & 0.794 & 0.737 & 0.685 & 0.637 & 0.592 & 0.550 & 0.511 & 0.475 & 0.441 & 0.410 \\
\hline 0.44 & 0.857 & 0.795 & 0.738 & 0.684 & 0.635 & 0.589 & 0.547 & 0.507 & 0.471 & 0.437 & 0.405 \\
\hline 0.45 & 0.860 & 0.797 & 0.738 & 0.684 & 0.633 & 0.587 & 0.544 & 0.504 & 0.467 & 0.432 & 0.401 \\
\hline 0.46 & 0.863 & 0.798 & 0.739 & 0.683 & 0.632 & 0.585 & 0.541 & 0.501 & 0.463 & 0.428 & 0.396 \\
\hline 0.47 & 0.867 & 0.801 & 0.740 & 0.683 & 0.631 & 0.583 & 0.539 & 0.498 & 0.460 & 0.425 & 0.392 \\
\hline 0.48 & 0.871 & 0.803 & 0.741 & 0.684 & 0.631 & 0.582 & 0.537 & 0.495 & 0.457 & 0.421 & 0.389 \\
\hline 0.49 & 0.875 & 0.806 & 0.743 & 0.684 & 0.630 & 0.580 & 0.535 & 0.492 & 0.454 & 0.418 & 0.385 \\
\hline 0.50 & 0.880 & 0.809 & 0.744 & 0.685 & 0.630 & 0.579 & 0.533 & 0.490 & 0.451 & 0.415 & 0.382 \\
\hline \multicolumn{12}{|c|}{ Generalized Loss Function, $\chi$ varying between 0 and 1} \\
\hline 0.0 & 0.822 & 0.812 & 0.802 & 0.792 & 0.782 & 0.772 & 0.763 & 0.753 & 0.744 & 0.734 & 0.725 \\
\hline 0.1 & 0.733 & 0.723 & 0.713 & 0.703 & 0.694 & 0.684 & 0.675 & 0.666 & 0.657 & 0.648 & 0.639 \\
\hline 0.2 & 0.656 & 0.646 & 0.636 & 0.625 & 0.615 & 0.606 & 0.596 & 0.586 & 0.577 & 0.568 & 0.559 \\
\hline 0.3 & 0.596 & 0.584 & 0.572 & 0.561 & 0.549 & 0.538 & 0.527 & 0.517 & 0.506 & 0.496 & 0.486 \\
\hline 0.4 & 0.557 & 0.543 & 0.528 & 0.514 & 0.500 & 0.487 & 0.474 & 0.461 & 0.449 & 0.437 & 0.425 \\
\hline 0.5 & 0.545 & 0.526 & 0.508 & 0.490 & 0.473 & 0.456 & 0.440 & 0.425 & 0.410 & 0.395 & 0.382 \\
\hline 0.6 & 0.565 & 0.541 & 0.517 & 0.495 & 0.473 & 0.453 & 0.433 & 0.414 & 0.396 & 0.379 & 0.362 \\
\hline 0.7 & 0.617 & 0.586 & 0.557 & 0.529 & 0.503 & 0.478 & 0.455 & 0.432 & 0.411 & 0.390 & 0.371 \\
\hline 0.8 & 0.693 & 0.657 & 0.622 & 0.590 & 0.559 & 0.530 & 0.502 & 0.476 & 0.451 & 0.428 & 0.405 \\
\hline 0.9 & 0.786 & 0.745 & 0.706 & 0.669 & 0.634 & 0.601 & 0.570 & 0.540 & 0.512 & 0.485 & 0.460 \\
\hline 1.0 & 0.890 & 0.845 & 0.802 & 0.761 & 0.723 & 0.686 & 0.651 & 0.618 & 0.587 & 0.557 & 0.529 \\
\hline
\end{tabular}

Note: $\chi$ is the fraction of resource windfalls allocated to a sovereign fund, whereas $\mu$ measures the importance of consumption volatility in the government loss function.

Source: Author's calculations. 
Figure 1

Temporary Oil Price Shock: Full Spending of Resource Windfall

(D eviations from Baseline)
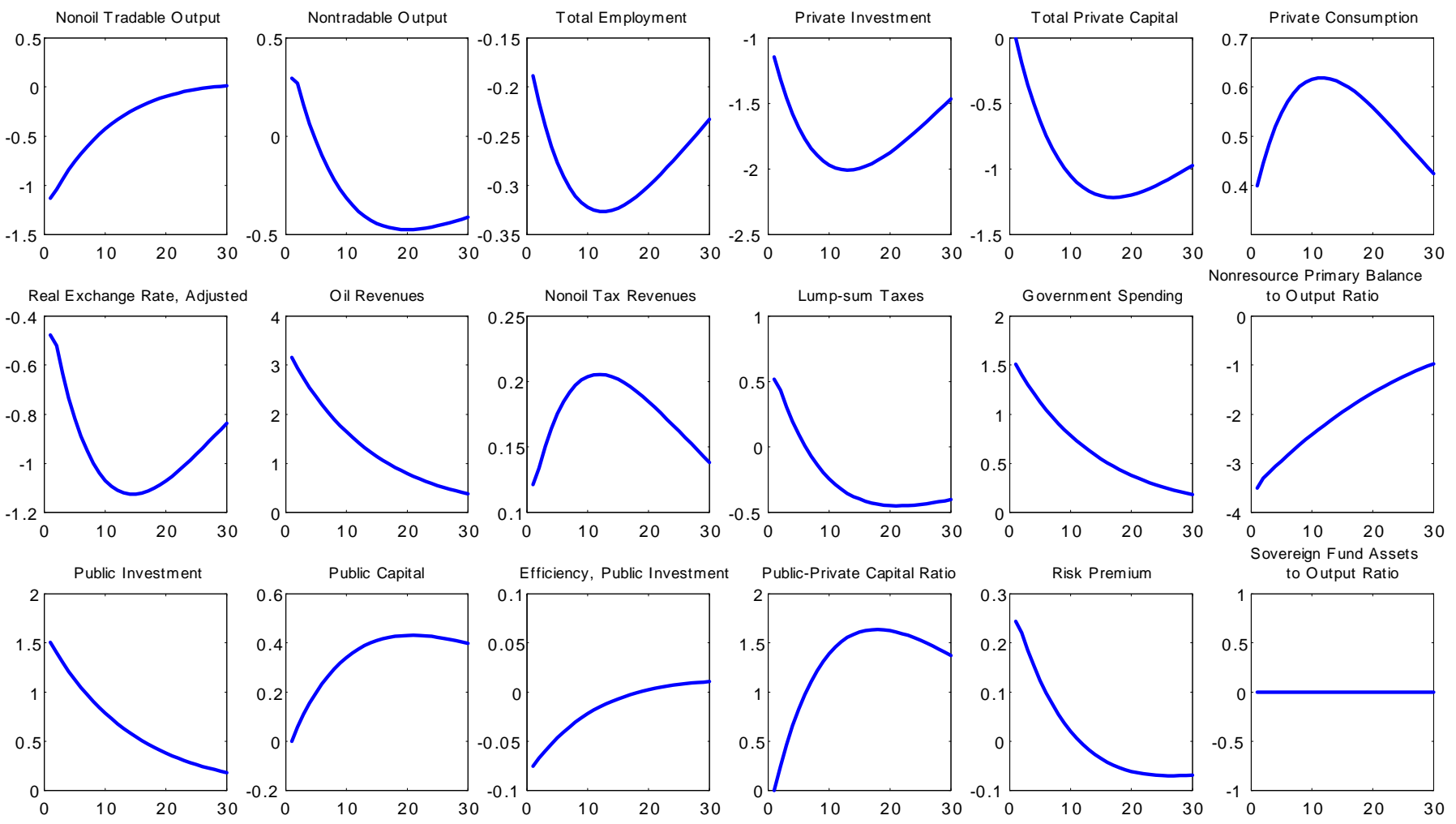


\section{Figure 2}

Volatility of Consumption and the Nonresource Primary Balance as a Function of the share of the Resource Windfall Saved

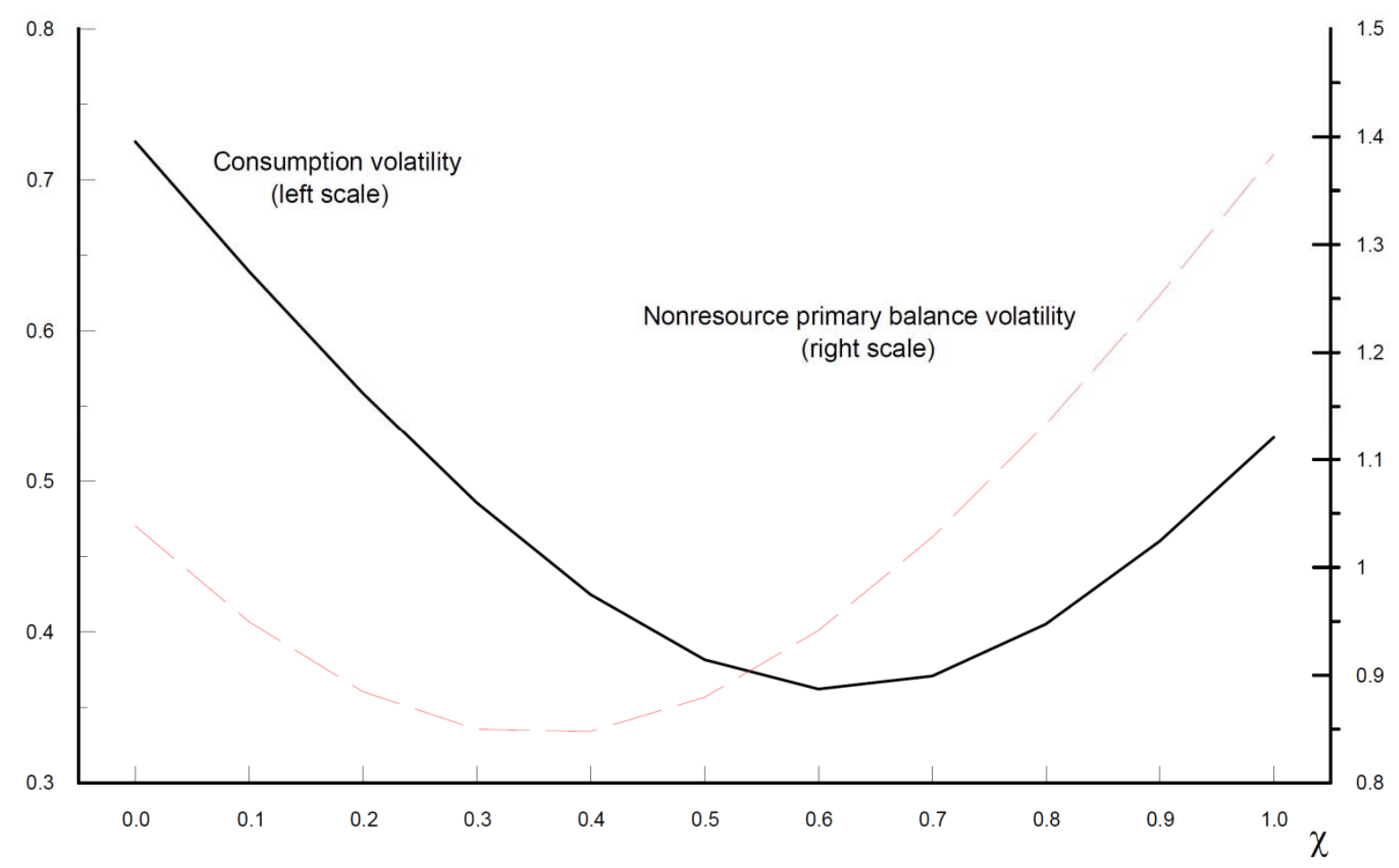

Note: $\chi$ is the share of the resource windfall allocated to accumulation in a sovereign fund. Volatility measures are the relative (normalized) standard deviations used to calculate the value of the fundamental loss function reported in Table 3 for $\mu=0.5$. 
Figure 3

Optimal Saving-Spending Allocation Parameter with Fundamental Loss Function

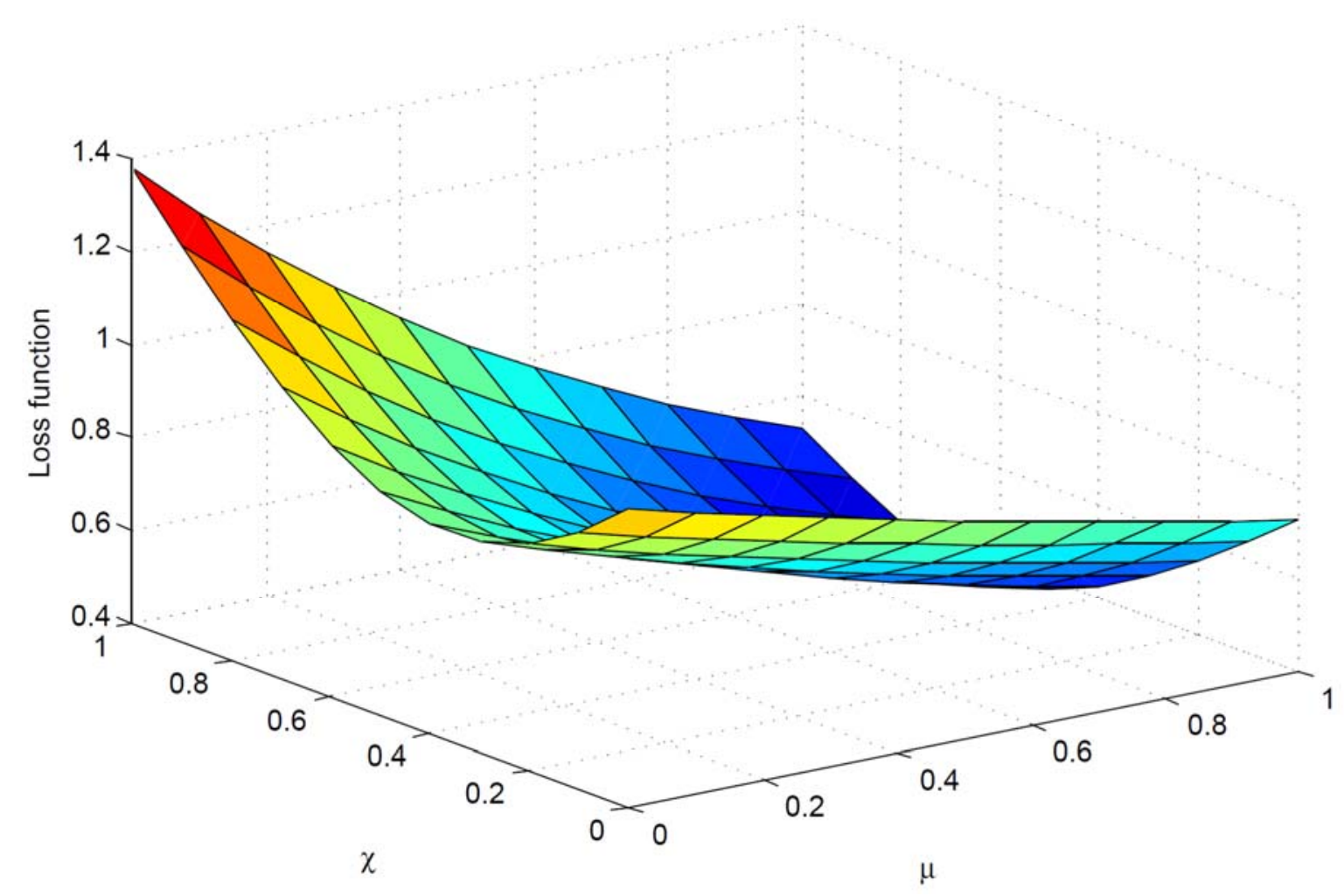

Note: $\chi$ is the share of the resource windfall allocated accumulation in a sovereign fund, whereas $\mu$ is the relative weight on (normalized) private consumption volatility in the loss function. 